\title{
Increasing Student Speaking Capability by Using Substitution and Convert Drills at State Senior High School Number 5 Kota Jambi
}

\author{
A Rasyid Ali \\ English Program Study of Tarbiyah Faculty and Teacher Training \\ State Islamic University of Sulthan Thaha Saifuddin Jambi \\ Email : rasyidali17@gmail.com
}

\begin{abstract}
The aim of this research is to investigate and to know about the strategy of learning speaking in English teaching, because there are many problems on teaching English, namely facility, method, media, and competency of teacher, capability of teacher, willingness of teacher, management of head Master, commitment of teacher, and discipline of teacher and student's competency. All the problems that previous above are very influence of English teaching quality, on particularly Learning Speaking, that is why the writer ( researcher ) eager to express of sharing idea, what happen on teaching and learning English, especially on Learning Speaking. Various strategies is very important on each teaching in order student does not feel bore to follow on learning English, Specially on Speaking, therefore in this opportunity the researcher introduce the strategy that used which is entitled "Substitution and Convert Drills".
\end{abstract}

Keyword:

Speaking, capability, Substitution and Convert Drills, and strategy

\section{INTRODUCTION}

"Substitution is a replacement of an item by a general word to avoid repetition"(Halliday \& Hasan, 1976: 88). There are three types of Substitution, namely Nominal, Verbal, and Clausal Substitution. (Halliday \& Hasan, 1976: 90)

1) Nominal Substitution

Halliday \& Hasan sates that Substitution is a replacement of ones instead of repeating the same word in nominal group.

Example: these biscuits stale. Get some fresh ones

2) Verbal Substitution is a placement of an element in verbal group and its position is always final in the group.

3) Clausal Substitution isa replacement of an entire clause

Substitution and Convert Drills are focused on repetition of pronunciation, and grammatical structural patterns by using oral over and over. These words come from " Substitute " means a person or thing that replaces( Oxford Advanced Learner's Dictionary ) and "Convert " means to change from one form or use to another ( Oxford Advanced Learner's Dictionary ). WEBSTER'S NEW WORLD DICTIONARY.

Drills are able to increase students to give immediately feedback. A drill is defined as "a type of highly controlled oral practice in which the students respond to a given cue "(Matthews, Spratt \& Dangerfield, 1991, p.210). Drills were usually generally used in the method of Audio Lingual which focused on imitate of pronunciation and grammatical structural pattern by using oral over and over.

Drills are one of the excellence ways for language practice over and over. Drills are able to improve students to use or to achieve target language. The students are engaged in drills, students are going to get stand a better opportunity of improving dialogues in real conversation or communication. Learning can be enjoyable by doing drill to improve learning environment.

\section{The use of Substitution and Convert Drill to increase Student Speaking}

Automatic student respond can be used by drilling over and over, because drills are sources of practice. Student will get highly motivated when they are able to quick respond the foreign language learning process.

As proverb say that practice makes perfect. As Larsen - Freeman ( 2000 ) comments " the more often something is repeated, the stronger the habit and the greater the learning "By doing good habits language practice, the student can express of language every day to each other. Rivers argues that "Foreign language learning is basically a process of mechanical habit formation. Good habits are formed by giving correct respond rather than be making mistakes. By memorizing dialogue and performing pattern drill the chances of producing mistakes are minimized "(1964, p.19-22)

Substitution and Convert Drills are able to enlarge speaking fluency and accuracy, and respond quickly. These substitution and Convert Drills are available the part of speech, grammatical, pronunciation, vocabulary, and tenses, etc:

This Substitution and Convert Drills student learn about grammar of the target language accurately. Learning structure through drills is not to make the student frustration, as they studied in an enjoyable learning 
environment, and use method of Active Learning. Furthermore, drills conducted in the classes can contribute to make good pronunciation.

Here, the student need to learn about how to substitute affirmative sentence to negative sentence, questions sentence, active to passive sentence, or direct speech to reported speech. These drills also facilitate the function of grammar by using Substitution and Convert Drills.

By doing Substitution and Convert Drills sometimes make the students boredom. Therefore, to increase students motivation to do the drills more motivating in learning process, Spratt (1991, p.10-11) makes some more suggestions :

1. They should look like real language, containing hesitation, proper social reactions such as exclamations, questions, or comments that require a respond. They can even consider register and nonverbal elements

2. The respond not be totally predictable; a variety of responses should be incorporated

3. They should involve genuine reactions between or among the speakers

4. They should be purposeful and based on topics of relevance to students

5. They should be sufficiently controlled and allow the teacher to observe how well learning has taken place

6 . They should allow for sustained language practice.

This Substitution and Convert Drills only imitate or repitation and make student bore, but not understanding the meaning. To avoid the errors, the teacher should elaborate clearly about meaning, grammar, pronunciation, vocabulary over and over.

\section{Nowadays Study}

The nowadays the study need the drills in language teaching, to role of drills to enlarge of speaking capability, to expose to a significant amount of L2 in their classes. The present formulation, namely:

1. Do the use of Substitution and Convert Drills make significant enlargement of speaking capability?

2. Do the use of Substitution and Convert Drills able to keep up of speaking capability?

\section{DATA AND RESEARCH METHOD}

Here the Researcher expresses the type of methodology, namely qualitative descriptive. Arikunto stated that descriptive qualitative is generally research design. Sugiyono also stated that qualitative is a research to examine the condition of natural objects.
In collecting the data, the researcher used observation and interview sheet which conducted at grade XI. IPA2, namely 21 male and 19 female.

\section{DISCUSSION AND CONCLUSION}

The nowadays study stated that the Substitution and Convert Drills in language teaching play role well in increasing student speaking capability, even though the student achievement is a litter bit differ to enlarge it. It considerable well to the student speaking capability. By doing these drills make the students add more knowledge about how to practice speaking capability well in grammar, pronunciation, enlarge vocabulary, etc.

\section{REFERENCES}

Arikunto, Suharsimi. (2002). Prosedur Penelitian: Suatu Pendekatan Praktik. Jakarta Rineka Cipta

Celse- Murcia,M (ed) (2001). Teaching English as asecond or Foreign Language Heinle \& Heinle US

Halliday\&Hasan. 1976. Cohesion in English. Oxford Advanced Learner's Dictionary Oxford Advanced Learner's Dictionary). WEBSTER'S NEW WORLD DICTIONARY.

Harmer Jeremy, (2007). The Practice of English Language Teaching. Pearson Education Limited Longman

Harmer Jeremy, (2007). How to teach English. Pearson Education Limited, Longman

Larsen- Freeman, D. (2000). Techniques and Principle in Language Teaching. Oxford; Oxford University Press.

Matthews, A, Spratt \&L. Dangerfield. (1991) At the Chalkface: Practical Techniques in Language Teaching. Walton- on- Thames, UK: Thomas Nelson.

Spratt, M. (1991)" The Practice Stage Discourse Chains. "In At the Chalkface: Practical Techniques in Language Teaching, eds. A. Mathews, M Spratt, and L. Dangerfield. Walton -on-Thames, UK: Thomas Nelson.

Sugiyono. (2013) Metode Penelitian qualitative, quantitative dan R\&D. Bandung; Alfabeta

Sugiyono. (2016) Memahami Penelitian qualitative. Bandung; 